\title{
CUIDADO CON LOS VIRUS HOAX
}

\section{BEWARE THE VIRUS HOAX}

\section{AUTORES}

Reynaldo Cordero Corro: Programador informático de la Universidad de Alcalá de Henares (España)

reynaldo.cordero@uah.es

\section{CURRÍCULUM VITAE DE CADA AUTOR}

Programador informático de la Universidad de Alcalá de Henares (España) y activista contra la ley del canon digital. Delegado sindical de CSIT-UP. Articulista habitual en foros sobre los derechos de copia y de autoría.

\section{RESUMEN}

En la jerga informática se conocen como "virus HOAX" (broma, engaño) y su difusión colapsa los servidores de correo y confunde -y a hace participar en la pamema- a un buen número de incautos. En realidad no son virus, pero su comportamiento "replicativo" hace que se los pueda considerar así en cierto modo.

\section{PALABRAS CLAVE}

Virus - HOAX - Bromas - Informática - Correo 


\begin{abstract}
In computer jargon are known as "virus HOAX" (joke, deceit) and diffusion-mail server crashes and mistakes, and to share in the pamema-to a number of unwary. In fact are not viruses, but their behavior "replicative" means that they can be considered so in a way.
\end{abstract}

\title{
KEY WORDS
}

Virus - HOAX - Jokes - Computer - Email

Como cualquier usuario de los servicios de correo electrónico, la redacción de Vivat Academia recibe avisos de existencia de virus "malísimos".

Estos avisos son en general falsos y el objetivo es que creamos que tienen valor y reenviemos el mensaje a nuestros amigos y conocidos.

En la jerga informática se conocen como "virus HOAX" (broma, engaño) y su difusión colapsa los servidores de correo y confunde -y a hace participar en la pamema- a un buen número de incautos. En realidad no son virus, pero su comportamiento "replicativo" hace que se los pueda considerar así en cierto modo.

El criterio general a seguir es que toda información recibida por correo cuyo origen no es conocido, debe considerarse inútil.

La información fiable, actualizada y en español acerca de virus de ordenadores la debemos buscar, cómo no, en las páginas de internet, como por ejemplo los didácticos Boletines Antivirus Paralax (http://www.paralax.com.mx/antivirus/), o la ofrecida por HispaSec (http:/ / www.hispasec.com/) de caracter más profesional. 
Pasamos a mostrar algunos ejemplos de HOAX que hemos recibido. NO DEJEN DE LEER EL ÚLTIMO, que es especialmente interesante.

VIRUS1: (información no contrastada, proviene de una cadena de correo múltiple) "VA EN SERIO, NO ES NINGUN CHISTE: Si recibes un email titulado "It Takes Guts to Say 'Jesus' ('Hacen falta narices para decir 'Jesús') " NO LO ABRAS. Borrará todo lo que tengas en el disco duro. Esta información fue anunciada ayer por la mañana por IBM; AOL indica que este es un virus muy peligroso, mucho peor que "Melissa", y que NO hay remedio para él en este momento. Algún individuo muy chiflado ha conseguido usar la función de reformateo de las Norton Utilities haciendo que borren completamente todos los documentos del disco duro. Ha sido diseñado para que funcione con Netscape Navigator y Microsoft Internet Explorer. Destruye los ordenadores personales MacIntosh e IBM compatibles. Este es un nuevo virus muy perverso y que no conoce mucha gente."

VIRUS2: (información no contrastada, también proviene de una cadena de correo múltiple)

"Queridos amigos, Si recibís un e-mail que ponga "PLEASE HELP POOR DOG WinA Holiday" no abrirlo es un virus que borra el disco duro".

VIRUS3: (Esta información es fidedigna. Quizás deberíamos haber incluido este texto en otra página de la revista, pero opinamos que éste es su verdadero sitio, ya que el virus existe, es realmente maligno, difícil de detectar y, lo peor, no solamente se intruduce por internet). :-)

Si recibes un e-mail titulado "MALA RACHA" bórralo inmediatamente sin abrirlo. Es el virus más peligroso que circula por Internet.

Si lo activas, el virus te formateará el disco duro. No sólo eso, también cambiará las etiquetas a todos los disquetes que haya a menos de un metro de tu ordenador. A continuación bajará el termostato de tu frigorífico para que se funda el Hagen Dazs, borrará la banda magnética de todas tus tarjetas de crédito, desajustará el tracking de tu vídeo y se cargará con armónicos de campo subespacial cualquier CD que intentes reproducir. 
Le dará a tu ex-pareja tu nuevo número de teléfono. Echará anticongelante en tu pecera. Se beberá todas tus cervezas y dejará tus calcetines en el revistero cuando estes esperando una visita especial. Meterá un gatito muerto en el bolsillo de tu mejor traje y te esconderá las llaves del coche cuando vayas a salir hacia el trabajo con el tiempo justo.

Mala Racha conseguirá que te enamores desesperadamente de un pingüino y que tengas pesadillas con una troupe de enanos. Te echará azucar en el depósito de la gasolina y te afeitará las cejas, antes de quedar con tu actual pareja a tus espaldas y cargar la cena y la habitación del hotel en tu Visa.

Cambiará tu coche de aparcamiento continuamente para que no lo encuentres. Se liará a patadas con tu perro. Dejará mensajes obscenos en el contestador de tu jefe... con tu voz.

Se trata de un virus insidioso y muy sutil. Es muy peligroso y sus efectos son devastadores. Y tiene unos reflejos malva totales". 